\title{
THE IMPLEMENTATION OF NUMBERED HEAD TOGETHER MODEL TO IMPROVE STUDENTS' ACCOUNTING LEARNING ACTIVITY
}

\author{
IMPLEMENTASI MODEL NUMBERED HEAD TOGETHER UNTUK \\ MENINGKATKAN AKTIVITAS BELAJAR AKUNTANSI SISWA
}

\author{
By : \\ Frank Aligarh \\ Accounting Education Department Yogyakarta State University. \\ frankaligarh@yahoo.com \\ Annisa Ratna Sari, M.S.Ed \\ Lecturer Accounting Education Department Yogyakarta State University
}

\begin{abstract}
This study is categorized as a classroom action research that aims to improve the Accounting Learning Activities of the students of class XI Accounting 1 SMK N 1 Depok Sleman academic year 2013/ 2014. This study is a collaborative research which is conducted in two cycles using the two methods of data collection which are observation and questionnaire. The data is first collected and then analyzed by the analysis of qualitative data through two stages, namely the presenting the data and drawing the conclusions. Qualitative analysis is then fitted with a descriptive analysis using quantitative percentage to calculate the score Accounting Learning Activities. Based on the results of the study, it can be concluded that the implementation of Cooperative Learning Model using Numbered Head Together type can improve Accounting Learning Activities of the students of Class XI Accounting Skills Competency SMK N 1 Depok Sleman Academic Year 2013/ 2014. It is evidenced by an increasing score on Accounting Learning Activities of the students' of class XI Accounting 1. It increased from $67.30 \%$ in the first cycle to $83.04 \%$ in the second cycle. It also shows that the average score of students' Accounting Learning Activities in the second cycle has reached the expectation score, i.e. $75 \%$.
\end{abstract}

Keywords: Cooperative Learning of NHT type, Activity, Accounting Learning Activity

\begin{abstract}
Abstrak
Penelitian ini merupakan Penelitian Tindakan Kelas yang bertujuan untuk meningkatkan Aktivitas Belajar Akuntansi siswa kelas XI Akuntansi 1 SMK N 1 Depok Sleman tahun pelajaran 2013/2014. Penelitian ini merupakan penelitian kolaboratif yang dilakukan dalam dua siklus dengan menggunakan dua metode pengumpulan data yaitu observasi dan angket dimana data yang terkumpul kemudian dianalisis dengan analisis data kualitatif melalui dua tahap, yaitu penyajian data dan penarikan kesimpulan. Analisis kualitatif tersebut kemudian dilengkapi dengan analisis deskriptif dengan menggunakan presentase kuantitatif untuk menghitung skor Aktivitas Belajar Akuntansi. Berdasarkan hasil penelitian disimpulkan bahwa implementasi Model Pembelajaran Kooperatif tipe Numbered Head Together dapat meningkatkan Aktivitas Belajar Akuntansi Siswa Kelas XI Kompetensi Keahlian Akuntansi SMK N 1 Depok Sleman Tahun Pelajaran 2013/2014 dibuktikan dengan adanya peningkatan skor Aktivitas Belajar Akuntansi kelas XI Ak 1 dari 67,30\% pada siklus pertama dan pada siklus kedua mencapai 83,04\%. Hal ini juga menunjukkan bahwa skor rata-rata Aktivitas Belajar Akuntansi pada siklus 2 sudah melampaui target indikator keberhasilan sebesar $75 \%$.
\end{abstract}

Kata kunci: Pembelajaran Kooperatif tipe NHT, Aktivitas, Aktivitas Belajar Akuntansi 


\section{A. INTRODUCTION}

The existence of central issues of intelligent, skilled, and qualified people can be developed by improving the quality of education. Education becomes a pillar of development for a country to be able to compete with the other countries around the world. The global threats and challenges may become a big problem for a country if it has not been already to face them. Therefore the dynamic planning and construction for education are need in order to be able to anticipate the global challenges. The education which is dynamic toward global changes will create an innovation and students' critical thinking so that the learning output may have good effect both academically and non academically. According to Dwi Siswoyo (2008:29), education is a planned effort in the process of coaching and learning for individuals in order to thrive and grow becoming people who are independent, responsible, creative, knowledgeable, healthy, and moralistic in terms of both physical and spiritual.

Students are those who continue to develop themselves as optimally as possible through the learning activities in order to achieve their goals that are appropriate to their development stages, while teachers are those who always strive for the right situation to allow the process of experiential learning on students by exerting all of learning resources and using appropriate learning strategies.

An effective learning process will enable students becoming active during the learning process. An active learning can only be done when a teacher has the ability to manage the class by using a variety of models. Teachers who are able to apply learning models which are creative, various, and focused more on the development of students' activities will make students more active in the learning process. Learning activities are all activities undertaken in the process of interaction (teachers and students) in order to achieve the learning objectives. Activities meant here put more emphasis on the students, because students' activities in the learning process can create an active learning situation.

Learning activities consist of physical and mental activities (Martinis Yamin: 2007). Physical activities are the activities in which students are actively involved in moving their bodies, making things, playing or working, not just sitting and listening, seeing, or just being passive. While the psychic activities occur when the students' soul works as much as possible or functions more within teaching and learning process. Students' activities in the learning process are really crucial - that is the ability to understand the acquired knowledge and skills to actualize this knowledge must be accompanied by good student activities.

One of the learning models which is able to create students' learning activities is Cooperative Learning Model. Cooperative learning is an instructional model making use of group system so that students here will learn actively in finding problems and solving those problems (Wina Sanjaya, 2011:241). One type of this cooperative learning model is Numbered Head Together type. This type is suitable to be applied in Accounting because it has a structure of learning materials that can be discussed.

Based on the preliminary observations conducted by the researcher at grade XI AK 1 SMK Negeri 1 Depok Yogyakarta, it was found that the learning activities are still low. Basically, the teacher has encouraged the students to ask, answer, or express their opinions. This low learning activity is not due to the lack of students' understanding regarding to the materials. Meanwhile this is because the students are more likely to 
remain silent and not too much dialogue occurs in the classroom. In case of understanding the materials, actually the students have already mastered the material but when the question and answer section is ongoing, the students tend to be hesitant and have lack of confidence in asking and answering the teacher. For instance, from 32 students in the class, there are only 8 students or 25 $\%$ were able to actively ask, answer and express opinions to the teacher. The rest of mostly $75 \%$ of students are passive in the class.

Based on the problems found, then there should be a solution regarding to those problems in order to improve the learning process that takes place in class XI AK 1 SMK Negeri 1 Depok Sleman Yogyakarta. The learning solutions are expected to be able to provide an improvement in the student activities. One of the learning models that can increase the students' activities in the learning process is cooperative learning model. Various types of cooperative learning include the Numbered Head Together type - this learning model emphasizes more on the student's activities. This NHT Model (Numbered Head Together) is indirectly train students to actively participate, share information, listen and speak carefully so that the students are more productive and active.

In accordance with the analysis that has been mentioned above, the researcher intends to conduct research entitled "The Implementation of Cooperative Learning Model Using Numbered Head Together Type to Improve Students' Learning Activities at Class XI Accounting 1 SMK Negeri 1 Depok Sleman Yogyakarta Academic Year 2013/2014"

\section{B. IDENTIFICATION OF THE PROBLEM}

From the background explained above, it can then be identified several problems as follows:
1. The teaching and learning process is lack of variation.

2. The teacher assesses the students' learning activities based on only whether or not students answer questions given by the teacher.

3. The instructional media the teacher uses have not maximally improved students' learning activities, so that the students only read books as the learning resources.

4. The students tend to be passive during the teaching and learning process.

5. The teacher has not used cooperative learning model especially the Numbered Head Together type during the learning process yet.

\section{RESEARCH OBJECTIVE}

This research will be conducted to achieve a purpose. The purpose is to improve the students' Accounting learning activities through the implementation of Cooperative Learning Model Using Numbered Head Together type on the students of Class XI Accounting 1, SMK Negeri 1 Depok Sleman Yogyakarta Academic Year 2013/2014.

\section{RESEARCH METHOD \\ 1. Research Design}

This research is a classroom action research in the form of collaboration. Wijaya Kusumah (2012:9) explains that classroom action research is a research conducted by teachers in their own classes by a way of planning, implementing, and reflecting actions collaboratively with the aim of improving their performance as teachers, so that the students' learning outcomes 
can be improved. In this research, the researcher and the teacher of the subject collaboratively carry out the research in two cycles.

\section{Research Place and Time}

The research will be conducted in class XI Accounting 1, SMK Negeri 1 Depok Sleman Yogyakarta which is located at Jalan Ring Road Utara, Maguwoharjo, Depok, Sleman, Yogyakarta and will be conducted in Oktober 2013 - Januari 2014. The steps taken are the preparation, execution and reporting steps.

\section{Research Subject and Object}

The subject of this research will be all students of class XI Accounting 1 SMK Negeri 1 Depok Sleman Yogyakarta Academic Year 2013/2014, which definitely 32 students. Meanwhile, the object of this study is the Students' Acounting Learning Activity at grade XI Accounting 1, SMK Negeri 1 Depok Sleman Yogyakarta Academic Year 2013/2014.

\section{Data Collection Techniques}

\section{a. Observation}

Observation is a data collection technique which is carried out by conducting direct observation toward the research's object and systematically recording the things being observed. In this research, observations are carried out with the aims of collecting the data on the students' Accounting learning activities during the teaching and learning process by making use of Cooperative Learning Model of Numbered Head Together Type.

\section{b. Questionaire}

According to Sugiyono (2012:199) "questionnaire is a data collection technique which is done by giving a set of questions or written statements to be answered by some respondents". This questionnaire used to obtain data on students' Accounting learning activities. By making use of the questionnaire in this study, the Accounting Learning Activity data can be obtained directly from the research - in this case are the students.

\section{Research Instruments}

\section{a. Field Notes}

Field notes are the forms used to record the implementation of actions during the teaching and learning process in which has been planned before. In this kind of notes, all activities did by the teacher and students inside the classroom will be recorded, such as the students' interaction with their teachers, and the students' interaction with their classmates, obstacles that appear during the "action" phase, etc. Later on, the information captured in the field notes can be used by the teacher and researcher in doing the "reflection" phase.

\section{b. Questionaire}

Questionnaire is an instrument used to find out information or data about the students' Accounting learning activities. The composing process of the questionnaire is based on the framework as the reference or basis in preparing the statements.

\section{c. Observation Sheets}

Observation sheets consist of two things, i.e. observation guidelines and list of observation indicators. Observations guidelines are required to help observer in doing the observation. It is a written guidances that include the indicators that will be observed and how to assess them. Based on the indicators which have been previously set, the aspects observed are: 
Reading the Accounting subject matter, Noting the Accounting subject matter, Conducting group discussions, Doing tasks and exercises given by the teacher, Answering some questions given by the teacher and classmates during the discussion, Responding to classmates' opinions, Doing quizzes given by the teacher independently.

\section{Research Procedure}

In this research, it will be conducted a collaboration between the researcher and the subject teacher. This research will be conducted in two cycles in which each cycle includes four phases: planning, action, observation stage, and reflection stage. The procedures are as follows:

1. Cycle I

a. Planning

At this stage, the researcher makes a deal with the teacher of the Accounting subject in class XI Accounting I SMK Negeri 1 Depok, Yogyakarta on the materials that will be used in the research. Besides, the researcher makes some Lesson Plans which include cooperative learning model of Numbered Head Together type. Finally, the researcher makes the observation sheets and questionnaires.

b. Action

This process is the process of the implementation of the planning that has been designed. Teachers implement the actions in the teaching and learning process using cooperative learning model of Numbered Head Together type.

c. Observation

The researcher will conduct observations while keeping records and giving scores on the observation guidelines of the students' activities. The researcher creates some notes on the field notes of the implementation of cooperative learning model of Numbered Head Together type.

d. Reflection

Reflection process is a process for assessing the actions the researcher had done toward the research subject. In this case, the reflection process is done by conducting some discussions with the subject teacher regarding the results of the field notes and observation sheets. Then, after reflection process has been done, evaluation of the implementation of the actions will be conducted. Also, the researcher will draw a conclusion about the identification of problems that arise during the learning process.

2. Cycle II

In this cooperative learning process of Numbered Head Together type, the activities in the second cycle are almost the same as the activities in the first cycle.

The difference lies on that the actions implemented in the second cycle are the rectified actions based on the reflection phase in cycle I. The second cycle activities aim to improve actions in previous cycle in order to achieve the success indicators. In addition, the implementation of Numbered Head Together can increase the activeness and level of participation of the students.

\section{Data Collection Techniques}

\section{a. Descriptive Data Analysis with Quantitative Percentage.}

Data obtained from the observations, in the form of rating scale, are quantitative data that show the assessment 
of the emergence of activities that reflect on Accounting Learning Activities in accordance with the aspects that have been prepared. Data from the results of the observations are then presented in the form of descriptive blurb.

\section{b. Qualitative Data Analysis}

This research uses qualitative analysis techniques which were developed by Miles Huberman used for qualitative research (Sugiyono, 2010: 338-345). The data analysis techniques of this research are as follows:

1) Data Presentation

What is meant by data presentation in this research is presenting the data in a simpler appearance which is in the form of narrative exposure, including the chart, flowchart, the relationship between categories and so on. It is intended to make it easier to understand the data and make plans based on what have been understood.

2) Conclusion Withdrawal

Conclusion withdrawal is the process of retrieving the important part of the organized data that has been presented. The conclusion is in the form of statements to answer the problem formulation that has been formulated formerly.

\section{Indicator of the Success on the Actions}

Indicators of the success of this research can be seen through the improvement of the students' Accounting learning activities at class XI Accounting 1 SMK Negeri 1 Depok Sleman Yogyakarta during the Accounting teaching and learning process takes place.

The improvement of the students' Accounting learning activities can be calculated based on the assessment of the
Accounting learning activities indicators predetermined. Then, the scores are summed and converted to percentage in a way of which the total score is divided by maximum score and then multiplied by $100 \%$. The learning process is successful if the whole or most $(75 \%)$ of the students are actively engaged both physically and mentally in the activities (Mulyasa, 2010: 218). The success of the actions is when each indicator set reaches at least $75 \%$.

\section{E. FINDINGS AND DISCUSSION}

The research which has been conducted is consisted of the stages of planning, action, observation and reflection. Observation phase, which is one step in the research has gained data showing the students' Accounting Learning Activities using Numbered Head Together type. In the cycle 1 and cycle 2 learning process showed some activities that reflect the Accounting Learning Activity $x$. The two cycles learning processes indicate the percentage of activity level that is then compared to determine the improvement on Accounting Learning Activities. The following table shows the improvement in Accounting learning activities of the students of class XI Accounting 1 SMK Negeri 1 Depok Yogyakarta Academic Year 2013/2014.

Table 1. The Score Comparison of Accounting Learning Activities Based on the Observation on the Cycle 1 and Cycle2

\begin{tabular}{|l|c|c|}
\hline \multicolumn{1}{|c|}{ Indicators } & \multicolumn{2}{|c|}{ Scores (\%) } \\
\cline { 2 - 3 } Cycle 1 & Cycle 2 \\
\hline $\begin{array}{l}\text { Reading the } \\
\text { Accounting } \\
\text { subject matter }\end{array}$ & $60,94 \%$ & $81,25 \%$ \\
\hline $\begin{array}{l}\text { Noting the } \\
\text { Accounting } \\
\text { subject matter }\end{array}$ & $75,78 \%$ & $89,06 \%$ \\
\hline $\begin{array}{l}\text { Doing tasks and } \\
\text { exercises given }\end{array}$ & $67,19 \%$ & $81,25 \%$ \\
\hline
\end{tabular}




\begin{tabular}{|l|c|c|}
\hline \multirow{2}{*}{ Indicators } & \multicolumn{2}{|c|}{ Scores (\%) } \\
\cline { 2 - 3 } & Cycle 1 & Cycle 2 \\
\hline by the teacher & & $81,25 \%$ \\
\hline $\begin{array}{l}\text { Conducting } \\
\text { group discussions }\end{array}$ & $64,84 \%$ & $82,03 \%$ \\
\hline $\begin{array}{l}\text { Answering some } \\
\text { questions given } \\
\text { by the teacher } \\
\text { and classmates } \\
\text { during the } \\
\text { discussion to }\end{array}$ & $71,09 \%$ & $79,69 \%$ \\
\hline $\begin{array}{l}\text { Responding to } \\
\text { classmates' } \\
\text { opinions }\end{array}$ & $71,09 \%$ & $86,72 \%$ \\
\hline $\begin{array}{l}\text { Doing quizzes } \\
\text { given by the } \\
\text { teacher } \\
\text { independently }\end{array}$ & $\mathbf{6 7 , 3 0 \%}$ & $\mathbf{8 3 , 0 4 \%}$ \\
\hline Average Score & & \\
\hline
\end{tabular}

Source: Primary Data Processed

Based on the data above it can be seen that there is an increase in Accounting learning activities level by making use of the Cooperative Learning Model using Numbered Head Together type from cycle 1 to cycle 2 .

In addition, the observation data on the cycle 1 and cycle 2 toward Accounting Learning Activities can be presented in the following graph:

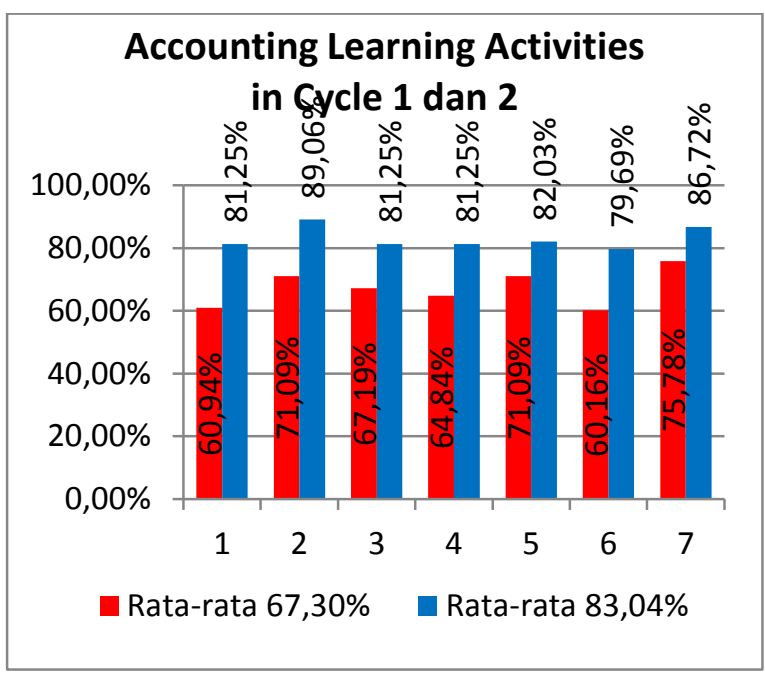

Figure 1. Observation Data Graph on Accounting Learning Activities of Cycle 1 and Cycle 2

In addition to using observations in analyzing the activities, some questionnaires were distributed at the end of each cycle. In this case, the questionnaires were distributed to students every learning process is completed. Here is the data from the questionnaires:

Table 2. The Score Comparison of Accounting Learning Activities Based on the Questionnaires on the Cycle 1 and Cycle 2

\begin{tabular}{|c|c|c|}
\hline \multirow{2}{*}{ Indicators } & \multicolumn{2}{|c|}{ Scores $(\%)$} \\
\hline & Cycle 1 & Cycle 2 \\
\hline $\begin{array}{l}\text { Reading the } \\
\text { Accounting } \\
\text { subject matter }\end{array}$ & $63,28 \%$ & $77,34 \%$ \\
\hline $\begin{array}{l}\text { Noting the } \\
\text { Accounting } \\
\text { subject matter }\end{array}$ & $65,63 \%$ & $76,56 \%$ \\
\hline $\begin{array}{l}\text { Doing tasks and } \\
\text { exercises given } \\
\text { by the teacher }\end{array}$ & $68,17 \%$ & $76,04 \%$ \\
\hline $\begin{array}{l}\text { Conducting group } \\
\text { discussions }\end{array}$ & $75,52 \%$ & $84,90 \%$ \\
\hline $\begin{array}{l}\text { Answering some } \\
\text { questions given } \\
\text { by the teacher and } \\
\text { classmates during } \\
\text { the discussion }\end{array}$ & $71,88 \%$ & $79,69 \%$ \\
\hline $\begin{array}{l}\text { Responding to } \\
\text { classmates' } \\
\text { opinions }\end{array}$ & $74,22 \%$ & $79,17 \%$ \\
\hline $\begin{array}{l}\text { Doing quizzes } \\
\text { given by the } \\
\text { teacher } \\
\text { independently }\end{array}$ & $63,29 \%$ & $78,13 \%$ \\
\hline Average Score & $67,30 \%$ & $83,04 \%$ \\
\hline
\end{tabular}

Based on the data from questionnaires above, it can be seen that there is an increase in Accounting learning activities level by making use of the Cooperative Learning Model using Numbered Head Together type from cycle 1 to cycle 2 . 
In addition, the questionnaire data on the cycle 1 and cycle 2 toward Accounting Learning Activities can be presented in the following graph.

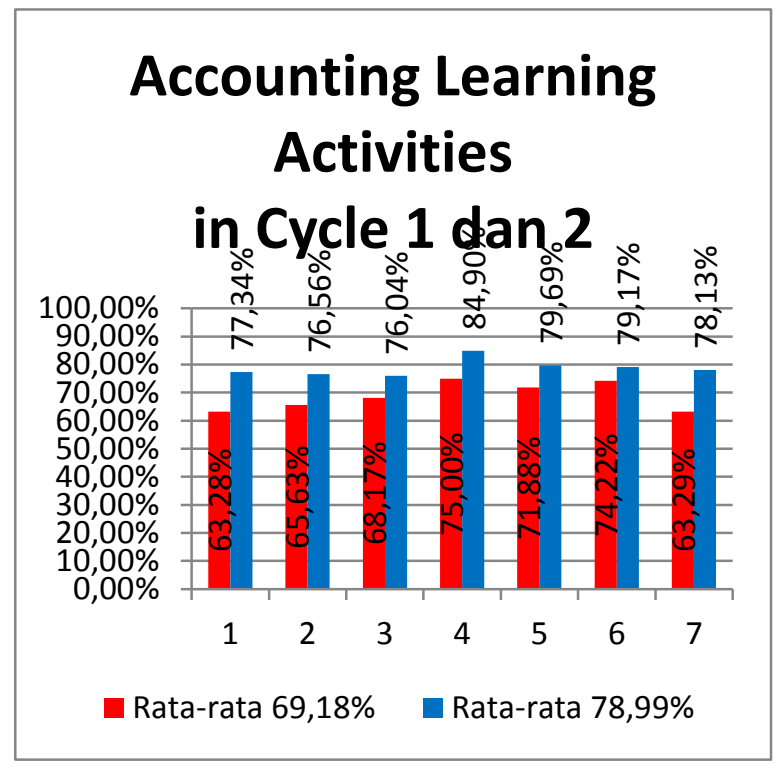

Figure 7. Questionnaire Data Graph on Accounting Learning Activities of Cycle 1 and Cycle 2

\section{F. CONCLUSION AND SUGGESTION}

\section{Conclusion}

Based on the findings and discussions of the research in chapter IV, it can be concluded that the implementation of cooperative learning model using Numbered Head Together type can improve Accounting Learning Activities of the students of class XI Accounting 1 SMK Negeri 1 Depok Yogyakarta Academic Year 2013/2014.

\section{Suggestion}

\section{a. For Teachers}

Teachers can apply various learning methods and techniques that can trigger the students' activeness in participating in learning activities. One variation that can be used is a cooperative learning model that there are various types included in it.
Cooperative learning model using Numbered Head Together can be used by teachers in relation to their willingness to increase students' learning activities. This learning model can be applied not only in learning Managing Debt Cards but also in many other learning activities with adjustments in them.From the research findings, the teacher should provide the opportunity for students to be independent and think of and perform their own problem solving so that the students will be familiar with the thinking. Teacher centered learning process will consequently lead the students tend to be less creative and passive.

\section{b. For the Researchers}

The researcher needs to be more careful to plann learning scenario.The researcher needs to be more careful to observing students for more detail individual analysis.

\section{G. REFERENCES}

Arikunto, Suharsimi. (2010). Prosedur Penelitian. Jakarta: Rineka Cipta

Lie, Anita. (2008). Cooperative Learning Mempraktikkan Cooperative Learning di Ruang-Ruang Kelas. Jakarta: Grasindo.

Mulyasa, E. (2010). Implementasi Kurikulum Tingkat Satuan Pendidikan, Kemandirian Guru dan Kepala Sekolah. Jakarta: Bumi Aksara

Purwanto, Ngalim. (2006). Psikologi Pendidikan. Bandung: Remaja Rosdakarya

Sanjaya, Wina (2011). Strategi Pembelajaran Berorientasi Standar Proses Pendidikan. Jakarta: Kencana 
(2009). Penelitian

Tindakan Kelas. Jakarta: Prenada Media Group

Sardiman, A. M. (2012). Interaksi dan Motivasi Belajar Mengajar. Jakarta: Rajawali Pers.

Sugihartono, (2007). Psikologi Pendidikan. Yogyakarta: UNY Press

Sugiyanto. (2010). Model-Model Pembelajaran Inovatif. Jakarta: Yuma Pustaka

Suprijono, Agus. (2012). Cooperative Learning Teori dan Aplikasi PAIKEM. Yogyakarta: Pustaka Belajar.

Trianto. (2013). Mendesain Model Pembelajaran Inovatif-Progresif. Jakarta:

Yamin, Martinis. (2007). Kiat Membelajarkan Siswa. Jakarta: Putra Grafika.

Yatim, Riyanto. (2009). Paradigma Baru Pembelajaran: Sebagai Referensi Bagi Pendidik dalam Implementasi Pembelajaran Yang Efektif dan Berkualitas. Jakarta: Kencana 